\title{
The Determinants of Online Vegetables/Fruits Repurchase Intention: Stimulus-Organism-Response Model and Theory of Planned Behaviour
}

\author{
Amir Fikri, Dr. (Cand.) \\ Faculty of Economic \& Business, Magister Management Programme, \\ Trisakti University, Jakarta, Indonesia \\ Graduate Student - School of Management and Business, \\ IPB University, Bogor, Indonesia \\ Rita Nurmalina, Prof. \\ Department of Agribusiness, Faculty of Economics and Management \\ IPB University, Bogor, Indonesia

\section{Mukhamad Najib, PhD} \\ Department of Management, Faculty of Economics and Management, \\ IPB University, Bogor, Indonesia \\ Megawati Simanjuntak, Dr. \\ Department of Family and Consumer Sciences, Faculty of Human Ecology, \\ IPB University, Bogor, Indonesia
}

Doi:10.19044/esj.2019.v15n10p147 URL:http://dx.doi.org/10.19044/esj.2019.v15n10p147

\begin{abstract}
The aim of this study is to review of concepts, theories and models related to consumer intentions. In doing this, the objective is to explore and explain the determinants of online vegetables/fruits repurchase intention based on literature review which used Stimulus-Organism-Response (SOR) Model and Theory of Planned Behaviour as basic concepts approach to put forward hypotheses for next research on consumer intention. Many research in the past examined variables as antecedents and predictors of repurchase intention. This literature study refers to the repurchase intention framework with a content of reputation, emotion, perceived risk, subjective norms, attitude, and perceived behavior control. The authors explore variables on these concepts, data for this study were generated through secondary data from many sources including paper, journal, textbooks, databases, and websites, etc. The literature review found that there is a positive relationship between reputation and emotion towards online repurchase intention, and perceived risk give a negative influence to online repurchase intention. The reputation of e-retailers is very important as it has a positive impact on online repurchase intention of e-
\end{abstract}


shoppers in the future. Subjective norms have a direct significant impact on buying intentions. Subjective norms influence attitudes toward buying intentions. That attitudes and perceived behavior control are better predictors of intentions when the social environment is more conducive and supportive to perform a behavior. The present study found that perceived behavioral control significantly influences willingness to online repurchase intention toward fresh vegetables or fruits. Hence, the study provides the summary of existing literature related to repurchase intention for better understanding and helps to frame the hypothesis for future research. While some outcomes may be significant to marketing practice, the overall goal of such research is to achieve a better understanding of consumer behavior.

Keywords: Emotion, Online, Perceived Risk, Repurchase Intentions, Reputation.

\section{Introduction:}

Repurchase intention of customers are the outcomes of some company efforts. Repurchase intention is among the most researched concept and the most important construct in practice now. Morwits et al., (2007) stated that many researchers use repurchase intention as a predictor for purchase behavior. A company always use repurchase intentions to make a prediction on sales in a variety marketing activities such as handling service management (Pereze et al. 2007), increase advertising effectiveness (Bird \& Ehrenbert, 1988) and introduce a new product (Silk \& Urban, 1978).

An online vegetables and fruits business operates anywhere in the word with the same principle. There is no deviation to the core of its operation. Online vegetables and fruits business is a startup that is growing very fast now. A lot of young businessmen are contemplating to start their online vegetables and fruit selling. The e-commerce business as a whole has increased tremendously over the last few years. Products of groceries including fruits and vegetables are now one of the many product categories that are being offered online. Various business models of vegetables and fruit online selling are: pick up fruits and vegetables from nearby outlets and delivery to the customer or pick up vegetables and fruits from farmers and delivery to the customer. As the trend of online business shopping began to develop, in the category of online grocery shopping there are several things that need to be anticipated. Market observation to various countries in the world shows that people prefer shopping directly to the store rather than other shopping methods. In fact, in most developed countries that have rapid growth in the online shopping industry, it is still not successful in developing sales of groceries products. In any country, the online shopping industry that offers 
groceries products has not developed rapidly. As with other products such as electronics, gadgets and other items that show improvement.

This theoretical research attempts to turn back the pages in literature, to understand the concepts and existing theories in the consumer buying behavior. This literature review refers to Stimulus-Organism-Response Model (Mehrabian \& Russel, 1974) and the Theory of Planned Behaviour (Ajzen, 1985), especially the actualization of online repurchase intention in vegetables and fruits e-commerce. This practical implication of the literature study in the vegetables and fruits e-commerce is extending past empirical research of online repurchase intentions. Focusing on three critical constructs on reputation, perceived risk, and emotion, this paper explores how the practical implications of these three constructs in vegetables and fruits e-commerce would influence online repurchase intentions.

\section{Stimulus-Organism-Response (SOR) Model}

SOR model was developed by Mehrabian and Russel (1974). In SOR Model, Environment as Stimulus is related to the individual's response (Response) and mediate by emotional states (Organisms). Responses to the environment can be considered as either approach or avoidance behaviors. Baker et al., (1992) and Viera (2013) suggested that the SOR Model can be adopted to understand the effect of environment on consumer behavior. Past research in retailing had adopted SOR Model and introduced Stimulus Organism as a set of mediating variables and behavior responses (Spies et al., 1997; Turley and Milliman, 2000; Yoo et al., 1998). The model indicated that environment as Stimulus factor can influence the consumer mood which evokes behavior response. Even though most past research had adopted SOR Model in retailing, the results are inconsistent and no general model has been introduced. Rosenbaum and Montoya (2007) stated that consumers who experience the environments might provide varied responses to the environment.

In this study, the stimulus is a characteristic of an agribusiness ecommerce environment, namely reputation that influences consumer emotional responses. Organisms refer to internal processes and structures as intervening between external stimuli with people and the final actions, reactions, or responses emitted. Whereas response consists of processes and structures that intervene perceptual, physiological, feeling, and thinking activities (Bagozzi, 1986).

The original S-O-R model focuses on Pleasure, Arousal (passion) and Dominance (PAD). PAD represents affective, emotional and cognitive conditions and processes and mediates the relationship between stimulus and individual behavioral responses (Mehrabian and Russell, 1974). In this study, positive emotional responses refer to consumers' positive feelings about the 
characteristics of the retail environment and represent the affective aspects of the organism's components as defined by Bagozzi (1986). The response in the $\mathrm{S}-\mathrm{O}-\mathrm{R}$ paradigm represents the end result and the final decision of the consumer, which can be an avoidance approach or behavior (Sherman et al., 1997).

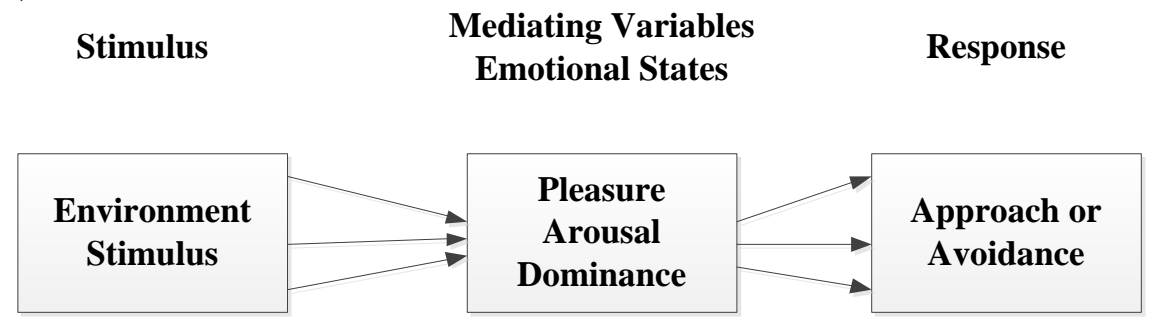

Figure 1 SOR Model (Mehrabian and Russel, 1974)

Approach behavior and the focus of the research represent positive action that may be directed to certain settings. For example, the intention to stay, browse, and make purchases can be a positive final action by consumers (Bitner, 1992; Mehrabian and Russell, 1974). Impulse buying behavior represents the approach aspect of the response component. This study focuses on positive emotional responses and approach behavior (repurchase intentions) because retailers generally try to create conditions that can generate positive feelings among consumers to encourage buying behavior. According to the theoretical framework, the individual nature of hedonic motivation was added as a moderator for the relationship between the characteristics of the retail environment and positive emotional response to these characteristics as suggested by previous studies (Massara and Pelloso, 2006; Ng 2003; Turley and Milliman, 2000). Researchers have suggested that environmental variables such as ambient, design, and social characteristics contribute to the perception of hedonic benefits associated with shopping experiences (Park, Kim, and Forney 2006).

\section{Theory of Planned Behaviour}

Ajzen (1985) developed TPB to explain the factors that determine behavioral intention of a person's attitude towards the behavior as shown in Figure 2. The first two factors are the same as TRA (Fishbein and Ajzen, 1975). The third factor is known as perceived control behavior where users feel that there is a limit to their behavior. 


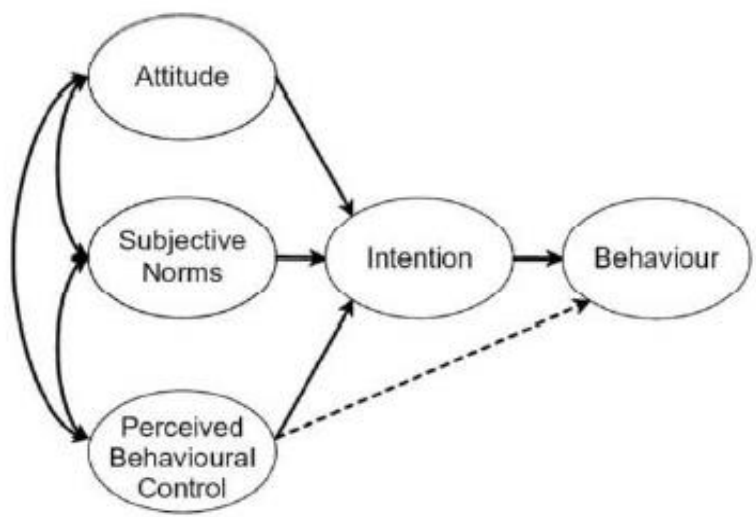

Figure 2 Theory of Planned Behaviour (Ajzen, 1985)

TPB in Chau and Hu's (2002) study notes that social norms and behavioral intentions to use technology are negatively correlated and do not support social norms that influence behavioral intentions. Shih and Fang (2004) also examined the internet banking adoption with the Decomposed TPB and TPB approaches and found that it was in line with Venkatesh and Davis (2000) findings that subjective norms tend to have a significant influence on behavioral intention to use in mandatory environment, while the effect can be insignificant in a voluntary environment.

\section{Online Repurchase Intention}

The use of the Internet for retail shopping has grown rapidly in recent years and has a profound influence on the shopping process for many consumers. Many cases were taken and purchased completely online (Brown et al., 2003). Furthermore, to understand the online shopping behavior mindset, online marketers are always compelled to explore the determinants of customer buying intentions online. The intention of purchase is the final consequence of a number of variations in the context of online shopping (Ling et al., 2010). Pavlou (2003) observes the intention of online purchases to be a more appropriate measure of intention to use a website when assessing consumer behavior online. Because online transactions involve sharing information and buying actions, buying intention will depend on many factors (Pavlou, 2003). The intention of a customer's purchase means the customer falls on the product and there is a possibility that he will buy it (Dodds et al., 1991; Afzali and Ahmed, 2016) and may change from certain products in one industry to another (Szymanski and Henard, 2001).

Intentions consist of motivational components of behavior (purchase) and are characterized by the degree of efforts one exerts to perform this behavior (Shim et al., 2001). A short intense flow state can move consumers to buy in a convenient manner by providing feelings of dominance that result 
from the flow while reducing the amount of deliberation time necessary before buying (Smith and Sivakumar, 2004). Shim et al. (2001) show that intention to use the Internet to search for information for search goods is not only the strongest predictor of Internet purchase intentions but also mediates the relationships between purchase intentions and predictors such as attitudes toward online shopping, perceived control and online purchase experience.

Chang, Eckman, and Yan (2011) conducted a study based on the Stimulus-Organism-Response (SOR) model to examine the direct and indirect effects of retail environmental characteristics on the impulse of buying behavior. The three characteristics (ambient, design, and social) of the retail environment affect the positive emotional response of consumers who, in turn, are affected by the impulsive behavior to buy. This study found a direct effect of (a) environmental characteristics/design of the retail environment on consumer positive emotional responses to the retail environment and (b) consumer positive emotional responses to the retail environment on impulsive buying behavior. Hedonic motivation moderates the relationship between the social characteristics of the retail environment and positive consumer emotional responses.

Kim and Lennon (2013) investigated cross-cultural differences in the impact of online retailer reputation and retail quality on consumers' emotional and cognitive (i.e. perceived risk) reactions, which lead to purchase intention, based on stimulus-organism-response (S-O-R) model. The results indicate that while the overall mechanism underlying the decision-making process is similar for the two countries, differences are found in the relative importance of the factors determining consumers' cognitive and emotional reactions as well as their intention to purchase online.

According to Cronin and Morris (1989) and Cronin and Taylor (1992), the purpose of repurchase intentions, referring to the psychological commitment to the product or service that arises after using it, generates ideas for consumption again (Jones and Sasser, 1995) found that repurchases intention is very important for store profit and evaluation. (Seiders et al., 2005) show repurchase intention refers to the extent to which consumers are willing to buy a product or service again. Simple, objective and easily observed expected buying behavior (Collier and Bienstock, 2006) also show that repurchase intention is not only possible to tend to buy the product, but it may also include the intention to recommend this to relatives and friends.

\section{Reputation}

The reputation of an e-agribusiness retailer is defined as the collective total of all previous transactions from retailers and requires the consistency of retailer's actions over a long period of time (Herbig and Milewicz, 1995). In this case, reputation is formed by the flow of information from one user to 
another user, which creates a halo effect that can be an external reference source (Jin et al., 2009). The halo effect can finally generate a favorable response in consumers even if the performance is not satisfactory. Furthermore, retailers' reputation influences consumer purchasing decisions as consumers are more likely to buy from established and reputable retailers than from unknown retailers (Lee and Shavitt, 2006). Reputation acts as a scheme, which has been developed through past experience with retailers. This scheme forms the basis for consumer expectations about future experiences with retailers (Estelami et al., 2004).

Reputation has often been suggested as a factor that reduces the risks perceived by consumers in sales organizations (Doney and Cannon, 1997). According to Chiles and McMackin (1996), companies with good reputation are considered reluctant to endanger their reputation assets by not fulfilling promises and obligations. Consumers consider a smaller risk in purchases from retailers who have a reputation for providing good service and quality products rather than from unknown retailers (Purohit and Srivastava, 2001). Also, the company's reputation has been found to reduce consumer concerns with self-disclosure (Andrade et al., 2002). These risk removers were found to limit a range of alternatives to well-known brands with good reputation (Dowling and Staelin, 1994; Van den Poel and Leunis, 1995). Lwin and Williams (2006) analyzed existing research on measurable risks and compiled a list of various risk removers in their study of perceived risks in online retailing.

Although the important role of reputation as an external frame of reference may play in determining the organism's response and consumer behavior caused by stimuli in e-Comemerce, there are few studies that examine the effect of reputation on producing positive or negative emotions. While reputation is found to be a strong predictor of perceived risk (Purohit and Srivastava, 2001), no research so far has examined the relationship between e-Commerce reputation and consumer emotions. The results of the study have suggested that reputation may have a positive influence on consumer perceptions or attitudes. Lee and Shavitt (2006) speculate that store reputation will influence the perception of online e-commerce sites. Jin et al. (2008) found a significant positive relationship between corporate reputation, e-satisfaction and e-trust. Because online retailers do not have person-toperson interactions that can function as an initial source of consumer influence, the main source of evaluating consumers from online retailers is a reputation that provides assurance. When this guarantee is present, it seems reasonable and correct to expect that consumers can experience positive emotions, even though this guarantee effect occurs unconsciously. 


\section{Emotion}

According to Mehrabian and Russell (1974), consumer emotions lead to various consumer response behaviors such as purchase intentions (Ha and Lennon, 2010; Wuet al., 2008) and approach behavior (Eroglu et al., 2003; Menon and Kahn, 2002; Wuetal ., 2008). A number of studies have found that consumer emotions play a major role in purchasing behavior, evaluation, and decision-making processes (Ladhari et al., 2008). Research conducted by Baker et al. (1992) found that the emotional state of consumers is positively related to the desire to buy.

According to research, emotion appears as a result of cognition (Scherer 1993). Lazarus (1991) further emphasizes that cognitive assessment is a necessity and sufficient for emotional formation. The results of the study indicate that the emotional response to events or stimuli is not dependent on events or stimuli themselves, but on the meanings that individuals give to events in the context of individual needs and potential coping (Frijda, 1993). This can explain why the same event can evoke emotions that are different from different individuals or why the same person can feel different emotions at different times when experiencing the same event. When an individual is faced with a different event, a specific emotion arises depending on the meaning a person gives to these events (Frijda, 1993). Research by Roseman et al. (1996) showed that expectations and fears of the outcome of events that were judged to be uncertain were caused by events that were considered as motives-consistent and certain. In studying consumers, some researchers investigated several aspects of the emotional-assessment relationship and found that consumer cognitive judgment produced consumer emotional responses (Nyer, 1997; Ruth et al., 2002).

\section{Perceived Risk}

The framework proposed by Roseman et al., (1996) explained that a certain combination of cognitive judgments (such as expectedness, probability and potential control) that determine emotions (such as surprise, hope, pleasure, help, liking, pride, fear, and sadness) will be experienced in certain situations. Perceived risk is defined as a function of uncertainty about the potential results of behavior in this study, we can predict that the perceived risk will affect consumers' emotions in online shopping situations. Based on this, the increased risk that is felt will lead to more negative emotions. Perceived risks refer to the spirit cost associated with customers' purchasing behavior, which represents a kind of uncertainty about the future. This uncertainty will directly affect the consumers' purchase intention. Due to the fact that network security is highly uncertain, consumers may worry about the illegal diffusion of personal and financial information. This will possibly affect their online shopping intentions. Over the past decades, perceived risk 
has been attributed as an important factor affecting the acceptance of consumer online shopping, and the online shopping risk can be classified into economic risk, performance risk, psychological risk, and time risk (Forsythe and Shi, 2003; Huang et al., 2014).

Perceived risk in online shopping is felt to be an obstacle in conducting internet-based transactions and thus it will affect consumers' choices to shop online (Gerrard and Cunningham, 2003; Kim and Forsythe, 2010; Rampl et al., 2012). In this study risk perception (perceived risk) consists of six dimensions, namely: financial risk, product risk, time risk, social risk, privacy risk and delivery risk. Previous research has explained that all these dimensions influence the interest in online shopping (online shopping intention).

According to studies (Thakur and Srivastava, 2015; Mwencha et al., 2014, and Masoud, 2013) financial risk refers to the perception that a number of values of money can be lost and other than that consumers feel about insecurity regarding the use of credit cards for online shopping transactions (Kolsaker and Payne, 2002). According to other researches (Thakur and Srivastava, 2015; Mwencha et al., 2014, Masoud, 2013, Kim et al., 2008) product risk is a consumer perception which states that a product purchased may not function as expected, and that its losses incurred due to the inability of buyers to accurately evaluate product quality through online services (Bhatnagar et al., 2000). Time risk, according to the research of Thakur and Srivastava (2015) and Masoud (2013), includes inconveniences arising during the online transaction process, difficulties in communicating with the seller, difficulties in giving instructions and/or shipping instructions or delayed reception of products by consumers (Forsythe et al., 2006).

Social risk, according to research conducted by Thakur and Srivastava (2015) and Masoud (2013), refers to the perception that purchased products can potentially lose status within consumer social groups because of either product inaccuracy or disagreement about internet use as a shopping method (Stone and Gronhaug, 1993). Privacy risk, according to the research of Thakur and Srivastava (2015), Mwencha et al. (2014) and Masoud (2013), shows that consumers are worried about disclosure or misuse of personal data information by a company as stated by Kesh et al. (2002) and Sathye (1999). Delivery risk is the potential of shipping losses related to items lost, damaged goods and goods being sent to the wrong address after buying (Dan et al., 2007). Time risk is the perception that the value of time, comfort, or effort may be in vain when the product purchased must be repaired or replaced / exchanged (Hanjun et al., 2004). The risk of time includes inconveniences arising during the online transaction process, communicating with online sellers (which will require a lot of time), difficulty in providing a clue and / or a shipping instruction or the delayed acceptance of products by consumers (Forsythe et al., 2006). 


\section{Trust}

In the beginning, the concept of trust was given as a good attitude belief to obtain information and purchases in a commercial setting. Further on, beliefs and attitudes attract perceived consequences (Hosmer 1995). Trust empowers positive expectations that no adverse or unfavorable results will occur if a trustor performs a behavior (Barber 1983). In short, trust creates a favorable perception of the results of e-commerce transactions, thus creating a favorable attitude. Regarding transactions, trust creates positive expectations that e-commerce merchants will fulfill their promises. Thus, researches conducted by Jarvenpaa et al. (2000), McKnight and Chervany (2002), and Pavlou (2003) show that trust has an impact on intention by creating a positive attitude.

According to Grönroos (2000), expectations for the behavior of both parties are shown in a predictable way that describes a trust or trust. Marketing literatures (Sirdeshmukhetal, 2002; Kim, Ferrin, \& Rao, 2003; Jinetal., 2012; Han \& Jeong, 2013) state that the achievement of customer satisfaction is largely determined by trust. When customers have confidence in the quality of services that will be provided to meet their needs, customers will decide to use the services and will establish cooperative relations between service users and service providers.

Trusts are referred as individual beliefs in the beliefs of others that can be determined by their perceived integrity, virtue, and competence (McKnight et al., 2002; Lin, 2011). Trusts are generally considered important in the online environment because of the risks associated in that context (Debei et al., 2014). Sichtmann (2007) states that there are two requirements that must be met to build trust, namely suppliers must have the competence and willingness to deliver products or services to the expected quality. This is also stated by several studies that show that competence has an influence on consumer trust (Sichtmann, 2007). Trust has been defined as an individual's perception of an institutional environment derived from socially embedded practices and perceptions, which are produced from the past and are expected to have future exchanges (Grabner-Kräuter, 2009). Trust is also defined as perceived credibility and virtue of the target trust (Doney and Cannon, 1997; Jevons and Gabbott, 2010)

\section{Attitude}

In many studies, attitude has been shown to influence behavioral interest (Ajzen and Fishbein, 1980). This relationship has received substantial empirical support. Regarding focus behavior, attitudes toward e-commerce adoption are defined as consumers desire to use e-commerce channels to obtain information and buy products from their respective e-commerce traders. The theory of planned behavior has been used by many studies to 
model organic food choices and attitudes have been indicated as significant predictors of purchase intention (Saba \& Messina, 2003; Chen, 2007; Gracia \& de Magistris, 2007; Setiawati et al., 2018; Shabrina et al., 2018). Preliminary studies have found that consumers' intention to buy organic food is usually a result of their positive attitude towards organic food. The more positive the attitude of the consumer is, the stronger the intention to carry out such behavior (Ajzen, 1991). A study by Saba and Messina (2003) found attitudes to be a significant predictor of the intention to eat organic fruits and vegetables. Even though, study by Fathia et al. (2018) did not find a significant relationship between attitude and willingness to pay for organic rice.

Attitude is a psychological construct (Jung, 1971), which is shaped by cognition (thought), values (beliefs) and affection (emotions) toward a particular object (Hoyer and Maclnis, 2004; Dossey and Keegan, 2008). Thøgersen (2009) and Michaelidou and Hassan (2008) revealed that "belief" about the consequences (better taste, healthy, and environmentally friendly) is instrumental in leading consumers toward organic food consumption. RoitnerSchobesberger et al. (2008) further stressed that health consciousness factor was one of the main driving forces in selecting organic food in Thailand. Moreover, in forming cognition process in buying products, environment friendliness was considered as a major element in opting for organic food in Norway (Honkanen et al., 2006). Furthermore, positive attitude related to product labeling, believability of advertising and certification from opinion leaders builds trust and confidence while choosing products. Trustworthiness was considered as major emotional variable for Italian buyers (Perrini et al., 2010). In the light of aforementioned literature, it is hypothesized that attitude has a positive effect on organic food purchase intention.

\section{Subjective Norms}

Subjective norms are normative beliefs of a social environment when a person behaves. Normative beliefs have a considerable impact on people who influence individuals (Montano and Kasprzyk, 2008). In Subjective Norms, this is divided into two, namely Normative Trust and Motivation to obey it (Levine et al., 1999). Normative belief is someone's view of what others think when he does an act, while the motivation to obey is the tendency of a person to behave in accordance with the beliefs of a group in which he is incorporated (Fishbein and Ajzen, 1980). The research conducted by Tarkiainen and Sundqvist (2005) states that subjective norms can influence behavior through attitude parameters, meaning that subjective norms can influence attitudes and attitudes that can influence behavior. It is also mentioned that a person's behavior is associated with subjective attitudes and norms. Zhang et al. (2015) found that community members who are more 
committed are expected to generate positive beliefs about the product within the communited which influenced behavior.

Subjective norms are related to social influences to carry out certain activities or behaviors (O’Neal, 2007). Subjective norms reveal the perception of a reference group if someone does a certain behavior. Previous research conducted by Tarkiainen and Sundqvist (2005), Setiawati et al. (2018) and Nugroho et al. (2018) found that in subjective norms are related to attitudes, and both can influence behavior, namely intention to buy. In 1998, Chang proposed an in-depth study of the influence of subjective norms on attitudes of individuals. Tarkiainen and Sunqvist (2005) conducted a study continuing previous research and they found a significant influence between subjective norms and attitudes, with examples of buying organic food. Another study by Venkatesh and Davis (2000) also found the concept of the relationship between subjective norms and behavior. In this theory it is said that social effects play an important role for a person to carry out certain behaviors and subjective norms are one's perceptions of the importance of doing or not doing a behavior. In addition there are two theories, namely Theory of Reasoned Action and Theory of Planned Behaviour, which reveals that the factors that influence the intention to behave are subjective norms.

\section{Perceived Behaviour Control}

Perceived behavioral control concerns with individuals' own judgment about their capabilities to engage in a particular behavior (Ajzen, 1991). It refers to the perception of the people about available resources such as buying power (as organic food is comparatively expensive than non-organic food) and availability of time which is also quite crucial (as people need to find specialty shops to buy organic food) in many countries like Italy, Germany, Spain, and the Netherlands (Tarkiainen and Sundqvist, 2005). Thøgersen (2009) opined that perceived behavioral control, shaped by perceived barriers and perceived ability, influences organic food buying behavior. Perceived barriers such as price and availability are significant obstacles that hinder organic food consumption (Magnusson et al., 2001; Hill and Lynchehaun, 2002; Vindigni et al., 2002; McEachern and Willock, 2004; Padel and Foster, 2005; Krystallis and Chryssohoidis, 2005; Hughner et al., 2007; Rodrı'guez et al., 2008). In case of perceived abilities, majority of past studies have attributed income or financial resources as essential determinants of willingness to purchase organic food (Jager, 2000; Torjusen et al., 2004; Kuhar and Juvancic, 2005; Gracia and de Magistris, 2007; Zepeda and Li, 2007; Riefer and Hamm, 2008)

\section{Conclusion}

This study is a review of concepts, theories and models related to consumer intentions based on SOR model and Theory of Planned Behaviour 
approach. The results from the SOR model revealed that there is a positive relationship between reputation, emotion and repurchase intention. This implies that the more positive reputation and emotion towards online fruits and vegetables, the higher the likelihood of repurchases. The results reveal that reputation and emotion are dominantly affecting the willingness of consumers to repurchase vegetables/fruits online. On the other side, based on theory of planned behavior approach revealed that perceived risk are less significant and perceived risk may have a negative impact on the willingness to buy. The more great the perceived risk of the consumer, the lower the intention to buy. This finding also supports that reputation and emotion factors determines repurchase intention as response. The study found that subjective norms have a much superior role in shaping buying intentions than what is generally perceived by a vast majority of researchers. Subjective norms have a direct significant impact on buying intentions. It is in line with the findings of previous studies. In addition, subjective norms influence attitudes toward buying intentions. Furthermore, subjective norms moderate the relationship between perceived behavioral control and buying intentions, and the relationship between attitude and buying intentions. This finding is consistent with the study performed by Povey et al. (2000) who found that attitudes and perceived behavior control are better predictors of intentions when the social environment is more conducive and supportive to perform a behavior. The present study found that perceived behavioral control significantly influences willingness to online repurchase intention toward fresh vegetables/fruits.

Based on the results of these the literature study, it is expected to be a source of ideas for making a hypothetical framework regarding the research of online repurchase intention for fresh fruits and vegetables in the future. It is hoped that these findings will enrich the analysis of factors that determine the online repurchase intention.

\section{References:}

1. Afzali, M., Ahmed, E.M. (2016). Exploring consumer doubt towards local new products innovation and purchase intention. World Journal of Entrepreneurship, Management and Sustainable Development, Vol. 12 Issue: 1, pp.2-17.

2. Ajzen, I. (1991). The theory of planned behavior, Organizational Behavior and Human Decision Processes, Vol. 50 No. 2, pp. 179-211.

3. Ajzen, I., Fishbein, M. (1980). Understanding Attitudes and Predicting Social Behavior, Prentice-Hall, Englewood-Cliffs, New York.

4. Ajzen, I. (1991). "The theory of planned behavior", Organizational Behavior and Human Decision Processes, Vol. 50 No. 2, pp. 179-211. 
5. Al-Debei, M.M., Akroush, N., Ashouri, I.M. (2014). Consumer Attitudes Towards Online

6. Shopping, Internet Research, 25(5), 707-733.

7. Andrade, E.B., Kaltcheva, V., Weitz, B. (2002). Self-disclosure on the web: The impact of privacy policy, reward, and company reputation. Advances in Consumer Research. 29: 350-3.

8. Brown, M., Pope, P., Voges, K., (2003), "Buying or browsing?: An exploration of shopping orientations and online purchase intention", European Journal of Marketing, Vol. 37 Issue: 11/12, pp.1666-1684.

9. Bhatnagar, A., Misra, S., Rao, H.R. (2000). Onrisk, convenience, and internet shopping behavior.Associationfor Computing Machinery. Communications of the ACM.43(11): 98-110

10. Bitner, M.J. (1992). Servicescapes: The impact of physical surroundings on customers and employees. Journal of Marketing, 56(2): 57-71.

11. Chilis, T.H., Mc Mackin, J.F. (1996). Integrating variable risk preferences, trust, andtransaction cost economics. The Academy of Management Review, 21(1): 73-99. doi:10.2307/258630.

12. Chang, H.J., Eckman, M., Yan, R.N. (2011). Application of the Stimulus-Organisme-Response Model to the retail environment: the role of hedonic motivation in impulse buying behavior. The International Review of Retail, Distribution and Consumer Research, 21(3): 233-249.

13. Chang, M.K. (1998). Predicting unethical behavior: a comparison of the theory of reasoned action of the theory of planned behavior. Journal of Business Ethics, Vol. 17 No. 16, pp. 1825-1833.

14. Dan, Y.,Taihai, D., Ruiming, L. (2007). Study of Types, Resources and Their Influential Factors of PerceivedRisks in Purchase Online. Journal of Dalian University of Technology, 28 (2): 13-19.

15. Dodds, B.K., Monroe, K.B., Grewal, D. (1991). Effect of price, brands and store information on buyers' product evaluation. Journal of Marketing Research, Vol. 28, August, pp. 307-319.

16. Doney, P.M., Cannon, J.P. (1997). An examination of the nature of trust in buyer-seller relationships. Journal of Marketing, 61: 33-51

17. Doney, P.M., Cannon, J.P. (1997). .An Examination of the Nature of Trust in Buyer-Seller Relationships. Journal of Marketing, Vol. 61 No. 2, pp. 35-52.

18. Dossey, B.M., Keegan, L. (2008). Holistic Nursing: A Handbook for Practice, Jones and Bartlett Learning, Sadbury, MA.

19. Estelami, H., Grewal, D., Roggeveen, A.L. (2004). The effect of retailer reputation and 
20. response on post purchase consumer reactions to price-matching guarantees. MSI Reports Working Paper, 3(04-003): 27-47.

21. Eroglu, S.A., Davis, I., Mahleit, K.A. (2003). Empirical testing of a model of online store atmospheric and shopper responses. Psychology and Marketing, 20(2): 139-150. doi: 10.1002/mar.10064

22. Fathia, Q.N., Nurmalina, R., Simanjuntak, M. (2018). Consumer's Attitude and Willingness to Pay for Organic Rice. Indonesian Journal of Business and Entrepreneurship. 4(1) : 11-21. http://dx.doi.org/10.17358/ijbe.4.1.11

23. Frijda, N.H. (1993). Appraisals and beyond. Cognition and Emotion 7: 225-31.

24. ForsytheS., Liu C., Shannon, D., Gardner, L. (2006). Development of a scale to measure the perceived benefits and risks of online shopping. Journal of Interactive Marketing, 20(2): 55-75

25. Gracia, A., de Magistris, T. (2007). Organic food product purchase behaviour: a pilot study for urban consumers in the South of Italy. Spanish Journal of Agricultural Research, Vol. 5 No. 4, pp. 439-451

26. Gerrard, P., Cunningham, J.B. (2003). The diffusion of Internet banking among Singapore consumers. International Journal of Bank Marketing, 21(1): 16-28. doi: 10.1108/02652320310457776.

27. Grönroos, C. (1984). A Service Quality Model and its Marketing Implications. European Journal of Marketing, 18(4), 36-44.

28. Grabner-Krauter, S. (2009). Web 2.0 Social Networks: The Role of Trust. Journal of Business Research, Vol. 90 No. 4, pp. 505-522.

29. Hanjun, K., Jaemin, J., Joo Young, K., Sun Wook, S. 2004. Cross cultural differences in perceived risk of online shopping. Journal of Interactive Advertising, 4(2): 20-29.

30. Ha, Y., Lennon, S.J. (2010). Effects of site design on consumer emotions: role of product involvement. Journal of Research in Interactive Marketing, 4 (2): 80-96.doi: 10.1108/17505931011051641

31. Hoyer, W., Maclnis, D.J. (2004). Consumer Behavior.Houghton Mifflin. Boston, MA

32. Han, H, Jeong, C. (2013). Improving Epistemological Beliefs and Moral Judgment Through an STS-Based Science Ethics Education Programme. Science and Engineering Ethics, 1-45

33. Hill, H., Lynchehaun, F. (2002). Organic milk: attitudes and consumption patterns. British Food Journal. Vol. 104 No. 7, pp. 526542.

34. Hughner, R.S., McDonagh, P, Prothero, A., Shultz, C.J., Stanton, J. (2007). Who are organic food consumers? A compilation and review of why people purchase organic food. Journal of Consumer Behaviour, Vol. 6 Nos 2/3, pp. 1-17. 
35. Herbig, P., Milewics, J. (1993). The realionship of reputation and credibility to brand success. Journal of Consumer Marketing, 10(3): 18-24.doi:10.1108/

36. Huang, L., Feng, J., Yan, F. (2014). Study on the perceived risk about the online shopping for fresh agricultural commodities and customer acquisition. Asian Agriculture. Available Online at: https://EconPapers.repec.org/RePEc:ags: asagre: 180422

37. Honkanen, P., Verplanken, B., Olsen, S.O. (2006). Ethical values and motives driving organic food choice. .Journal of Consumer Behaviour, Vol. 5 No. 5, pp. 420-430

38. Jin, N., Lee, S., Huffman, L. (2012). Impact of Restaurant Experience on Brand Image and Customer Loyalty: Moderating Role of Dining Motivation. Journal of Travel and Tourism Marketing, 29(6), 532551.

39. Jevons, C., Gabbot, M. (2010). Trust, Brand Equity and Brand Reality in Internet Bussiness Relationships: an Interdisciplinarry approach. Journal of Marketing Management, Vol. 16 No. 6, pp. 619-634.

40. Jager, W. (2000). Modelling Consumer Behaviour. University of Groningen, Groningen

41. Jung, C.G. (1971). Psychological Types, Collected Works. Vol. 6, Princeton University Press, Princeton, NJ.

42. Kuhar, A., Juvancic, L. (2005). Modelling consumer preferences towards organic and integrated fruits and vegetables in Slovenia.paper presented at 97th EAAE Seminar on The Economics and Policy of Diet and Health, April 21-22, Reading, MA.

43. Kolsaker, Payne. (2002). Engendering trust in e-commerce: a study of gender-based concerns. Marketing Intelligence \& Planning, 20(4): 206-214. doi:10.1108/02634500210431595

44. Kim, D.J., Ferrin, D.L., Raghav Rao, H. (2009). Trust and satisfaction, two stepping stones for successful e-commerce relationships: A longitudinal exploration. Information Systems

45. Kim D., Ferrin D., Rao J. (2008). A trust-based consumer decisionmaking model in electronic commerce:The role of trust, perceived risk, and their antecedents. Decision Support Systems, 44:544-564.

46. Kim, J., Lennon. (2013). Effects of reputation and website quality on online consumers' emotion, perceived risk and purchase intention: Based on the stimulus-organism-response model. Journal of Research in Interactive Marketing, 7(1): 33-56. doi10.1108/17505931311316734

47. Kim, J., Yan,g K., Kim, B.Y. (2013). Online retailer reputation and consumer response: examining cross cultural differences. 
International Journal of Retail \& Distribution Management, Vol. 41 Issue: 9, pp.688-705, https://doi.org/10.1108/IJRDM-02-2012-0009

48. Magnusson, M.K., Arvola, A., Hursti, U.K.K., A berg., L.,Sjo"de'n, P.O. (2001). Attitudes towards organic foods among Swedish consumers. British Food Journal, Vol. 103 No. 3, pp. 209-227.

49. Kesh, S., Nerur, S.P., Ramanujan, S. (2002). A framework for analyzing e-commerce security. Information Management \& Computer Security, 10(4):149-158. doi: 10.1108/09685220210436930.

50. Kim, J., Forsythe, S. (2010). Factors affecting adoption of product virtualization technology for online consumer electronics shopping. International Journal of Retailing and Distribution Management, 38(3): 190-204.doi:10.1108/09590551011027122.

51. Kim J., Lennon. (2013). Effects of reputation and website quality on online consumers' emotion, perceived risk and purchase intention: Based on the stimulus-organism-response model. Journal of Research in Interactive Marketing. 7(1): 33-56. doi10.1108/17505931311316734

52. Krystallis, A., Chryssohoidis, G. (2005). Consumers' willingness to pay for organic food: factors that affect it and variation per organic product type. British Food Journal, Vol. 107 No. 5, pp. 320-343.

53. Lin, H.F. (2011). An empirical investigation of mobile banking adoption: the effect of innovation attributes and knowledge-based trust. International Journal of Information Management, Vol. 31 No. 3, pp. 252-260.

54. Ladhari, R., Morales, M., Brun I. (2008). Determinants of dining satisfaction and post dining behavioura; intention. International Journal of Hospitality Management. 27(4): 563-573. doi: 10.1016/j.ijhm.2007.07.025.

55. Lazarus, R.S. (1991). Emotion and Adaptation. Oxford University Press, New York, NY.

56. Ling, K.C., Chai, L.T,. Piew, T.H. (2010). The effects of shopping orientations, online trust and prior online purchase experience toward customers' online purchase intention. International Business Research, Vol. 3 No. 3, pp. 63-76.

57. Levine, T.R., Park, H.S., McCornack, S.A. (1999). Accuracy in detecting truths and lies: Documenting the "veracity effect". Communication Monographs, 66, 125144.

58. Lee, K., Shavitt, S. (2006). The use of cues depend on goals: Store reputation affects product judgement when social identity goals are salient. Journal of Consumer Psychology. 16(3): 260-271. doi: $10.1207 / \mathrm{s} 15327663 \mathrm{jcp} 1603 \_8$. 
59. Lee, K., Shavitt, S. (2006). The use of cues depend on goals: Store reputation affects product judgement when social identity goals are salient. Journal of Consumer Psychology. 16(3): 260-271. doi: 10.1207/s15327663jcp1603_8.

60. Lwin, M.O., Williams, J.D. (2006). Promises, promises: How consumers respond to warranties in internet retailing. Journal of Consumer Affairs, 40(2): 236-60.

61. Massara, F., Pelloso, G. (2006). Investigating the consumerenvironment interaction through image modeling technologies. International Review of Retail, Distribution and Consumer Research, 16(5): 519-31

62. McKnight, D.H., Chondhury, V., Kacmar, C. (2002), Developing and Validating Trust Measures for e-Commerce: An Integrative Typology. Information Systems Research, Vol. 13 No. 3, pp. 334-359.

63. Mc Eachern, M.G. Willock, J. (2004). Producers and consumers of organic meat: a focus on attitudes and motivations. British Food Journal, Vol. 106 No. 7, pp. 534-552.

64. Michaelidou, N., Hassan, L.M. (2008). The role of health consciousness, food safety concern and ethical identity on attitudes and intentions towards organic food. International Journal of Consumer Studies, Vol. 32 No. 1, pp. 163-170.

65. Menon, S., Kahn, B. (2002). Cross-category effects of induced arousal and pleasure on the internet shopping experience. J. Bus. Res, 78:3140.

66. Mehrabian, A., Russell J.A. (1974). An approach to environmental psychology. MIT Press.Cambridge, MA.

67. Montano, E., Kasprzyk, D. Theory Of Reasoned Action, Theory Of Planned Behavior, and The Integrated Behavioral Model. Health Behavior Theory, Research, And Practice, Vol. 5

68. Mwencha, P.M., Muathe, S.M., Thuo, J.K. (2014). Effects of perceived attributes, perceived risk and perceived value on usage of online retailing services. Journal of Management Research. 6(2): 140161.

69. Masoud, E.Y. (2013). The effect of perceived risk on online shopping in Jordan. Eropean Jurnal of Business and Management, 5(6).

70. Nyer, P.U. (1997). A study of the relationships between cognitive appraisals and consumption emotions. Journal of the Academy of Marketing Science, 25(4): 296-304.

71. Nugroho, A., Najib, M., Simanjuntak, M. (2018). Factors Affecting Consumer Interest In Electronic Money Usage With Theory of Planned Behavior (TPB). Journal of Consumer Sciences, 3 (1):15-27. http://dx.doi.org/10.29244/jcs.3.1.15-27 
72. O'Neal, P.W. (2007). Motivation of Health Behavior, Nova Publishers, New York, NY

73. Park, E.J., Kim, E.Y., Forney, J,C. (2006). A structural model of fashion-oriented impulse buying. Journal of Fashion Marketing and Management, 10(4): 433-46.

74. Pavlou, P.A. (2003). Consumer acceptance of electronic commerce: integrating trust and risk with the technology acceptance model. International Journal of Electronic Commerce, Vol. 7 No. 3, pp. 10134.

75. Padel, S., Foster, C. (2005). Exploring the gap between attitudes and behavior: understanding why consumers buy or do not buy organic food. British Food Journal. Vol. 107 No. 8, pp. 606-625.

76. Perrini, F.S.,Castaldo, N.M., Tencati, A. (2010). The impact of corporate social responsibility associations on trust in organic products marketed by mainstream retailers: a study of Italian consumers. Business Strategy and the Environment, Vol. 19 No. 8, pp. 512-526.

77. Purohit, D., Srivastava, J. (2001). Effect of manufacturer reputation, retailer reputation, and product warranty on consumer judgments of product quality: A cue diagnosticity framework. Journal of Consumer Psychology, 10(3):123-134. doi:10.1207/s15327663jcp10031

78. Roitner-Schobesberger, B., Darnhofer, I., Somsook, S. Vogl, CR. (2008).Consumer perceptions of organic foods in Bangkok, Thailand. Food Policy, Vol. 33 No. 2, pp. 112-121.

79. Ruth, J.A., Brunel, F.F., Otnes, C.C. (2002). Linking thoughts to feelings: Investigating

80. cognitive appraisals and consumption emotions in a mixed-emotions context. Journal of the Academy of Marketing Science. 30(1): 44-58.

81. Riefer, A. Hamm, U. (2008). Changes in families' organic food consumption. Paper presented at 12th Congress of the European Association of Agricultural Economists - EAAE, August 26-29, Ghent.

82. Rodri'guez E., Lacaze, V., Lup1'n, B. (2008). Valuation of consumers' willingness-to-pay for organic food in Argentina, paper presented at 12th Congress of the European Association of Agricultural Economists - EAAE, August 26-29, Ghent

83. Roseman, I.J., Antoniou, A.A., Jose, P.E. (1996). Appraisal determinants of emotions:

84. constructing a more accurate and comprehensive theory. Cognition and Emotion. 10: 241-77.

85. Shabrina, Z., Yuliati, L.N., Simanjuntak, M. (2018). The Effects of Religiousity, Pricing and Corporate Image on The Attitude and The Intention to Use Sharia Micro Financing. Indonesian Journal of 
Business

and

Entrepreneurship.

4(2):197-206. http://dx.doi.org/10.17358/ijbe.4.2.197.

86. Setiawati H., Hartoyo., Simanjuntak, M. (2018). Analysis on Intention of Purchasing Organic Foods by The Undergraduate Students of IPB Using The Theory of Planned Behaviour Approach. Journal of Management and Agribusiness. $15 \quad$ (2): 198-207. http://dx.doi.org/10.17358/jma.15.2.198.

87. Sirdeshmukh, D., Singh, J., Sabol, B. (2002). Consumer Trust, Value, and Loyalty. Journal of Marketing.Research, 20(2), 237-257.

88. Sichtmann, C. (2007). An Analysis of Antecedents and Consequences of Trust in a Corporate Brand. Marketing Management Journal, Vol. 41, No (9/10), pp. 999-1015

89. Stone, N.R., Grounhaug, K. (1993). Perceived risk: Further considerations for the marketing discipline. European Journal of Marketing, 27(3):39-50. doi: 10.1108/03090569310026637

90. Shim, S., Gehrt, K.C., Lotz, S.L. (2001). Export implications for the Japanese fruit market: fruit-specific lifestyle segments. International Journal of Retail \& Distribution Management, Vol. 29 No. 6, pp. 30016.

91. Szymanski, D.M., Henard, D.H. (2001). Customer satisfaction: a metaanalysis of the empirical evidence, Journal of the Academy of Marketing Science, Vol. 29 No. 1, pp. 16-35.

92. Scherer, K.R. (1993). Studying the emotion-antecedent appraisal process: An expert system approach. Cognition and Emotion, 7: 32555.

93. Shim, S., Eastlick, M.A., Lotz, S.L., Warrington, P. (2001). An online purchase intentions model: The role of intention to search. Journal of Retailing. 77:397-416

94. Thøgersen, J. (2009). Consumer decision making with regard to organic food products, in Vaz, M.T.D.N., Vaz, P., Nijkamp, P. and Rastoin, J.L. (Eds), Traditional Food Production Facing Sustainability: A European Challenge, Ashgate, Farnham, pp. 173-194.

95. Torjusen, H., Sangstad, L., O’Doherty Jensen, K., Kjaernes, U. (2004). European Consumers' Conceptions of Organic Food: A Review of Available Research. National Institute for Consumer Research, Oslo

96. Tarkiainen, A., Sundqvist, S. (2005). Subjective norms, attitudes and intentions of Finnish consumers in buying organic food. British Food Journal, Vol. 107 Nos 10/11, pp. 808-822

97. Turley, L.W., Milliman, R.E. (2000). Atmospheric effects on shopping behavior: A review of the experimental evidence. Journal of Business Research. 49: 193-211. 
98. Thakur R., Srivastava M. (2015). A study on the impact of consumer risk perception and innovativeness on online shopping in India. International Journal of Retail \& Distribution Management, 43(2): 148-166.

99. Vindigni, G., Janssen, M.A., Jager, W. (2002). Organic food consumption: a multi-theoretical framework of consumer decision making. British Food Journal, Vol. 104 No. 8, pp. 624-642.

100. Wei, Y., Wang, C., Zhu S., Xue, H., Chen, F. (2018). Online purchase intention: Antecedents in an integrated model based on technology acceptance model and perceived risk theory. Frontiers in Psychology, 9: 1521

101. Zepeda, L., Li, J. (2007). Characteristics of organic food shoppers. Journal of Agricultural Applied Economics. Vol. 39 No. 1, pp. 17-28

102. Zhang, J., Shabbir., Pitsapol, C., Hassan, W. (2015). Managing Consumer Commitment Through Online Brand Communities: Empirical Evidence From China. European Scientific Journal, Vo.11 No.1 